ENTREPRENEURSHIP AND SUSTAINABILITY ISSUES

ISSN 2345-0282 (online) http://jssidoi.org/jesi/

2021 Volume 9 Number 2 (December)

http://doi.org/10.9770/jesi.2021.9.2(12)
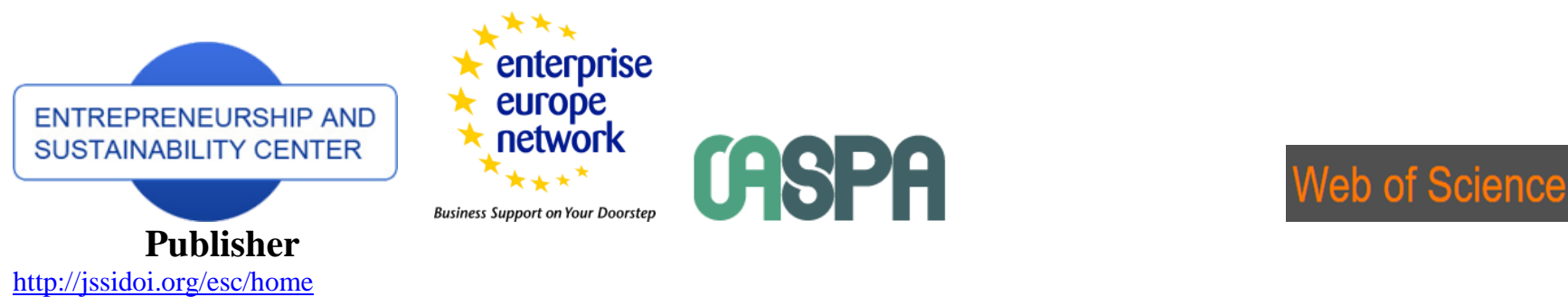

http://jssidoi.org/esc/home

\title{
ENTREPRENEURS' OPINION TOWARDS CREDIT RATING IN SAUDI ARABIA
}

\author{
Kamran Siddiqui ${ }^{1}$, Ishtiaq Bajwa ${ }^{2}$, Faisal Al-Hudithi ${ }^{3}$, Tarig Eltayeb ${ }^{4}$, Asma Khatoon ${ }^{5}$, \\ Suliman Bawardi ${ }^{6}$ \\ 1,2,3,4,5,6 Imam Abdulrahman Bin Faisal University, Dammam 31451, Saudi Arabia \\ E-mails:ㄹasiddiqui@iau.edu.sa; ${ }^{2}$ iabajwa@iau.edu.sa; ${ }^{3}$ faalhudithi@iau.edu.sa; ${ }^{4}$ tknourelhadi@iau.edu.sa; \\ 5akhusain@iau.edu.sa; ${ }^{5}$ suliman.y.b@hotmail.com
}

Received 15 May 2021; accepted 23 September 2021; published 30 December 2021

\begin{abstract}
This study aims to measure the entrepreneur's opinions towards their credit rating in Saudi Arabia. Credit rating plays a pivotal role in the financial market, especially its more significant impact on new startups from the micro and macro levels. On the other hand, the credit rating industry, in general, is in its infancy stage in the Saudi financial market. Therefore, a minor objective of this study is to present the problems and prospects of entrepreneurs towards their credit rating. The study has adopted the questionnaire from earlier research on credit rating. A sample of 210 respondents participated in this survey comprising entrepreneurs, business incubation managers, bankers, university professors, engineers, doctors, and other professionals. Descriptive statistics and Exploratory Factor Analyses were used to analyze the data. Findings show there are five essential factors affecting credit rating in Saudi Arabia, i.e., (1) Credibility, (2) Clarity, (3) Competence, (4) Communications, and (5) Customer Services. The research provides valuable insights into the credit rating business and recommends that CRAs in Saudi Arabia and elsewhere improve upon these five factors to strengthen their business.
\end{abstract}

Keywords: Credit Rating; Entrepreneur; Start-up; Entrepreneurial Finance; Saudi Arabia

Reference to this paper should be made as follows: Siddiqui, K.A., Bajwa, I.A., Al-Hudithi, F.A., Eltayeb, T.K., Hussain, A.K., Al Bawardi, S. 2021. Entrepreneurs' Opinion Towards Credit Rating in Saudi Arabia, Entrepreneurship and Sustainability Issues, 9(2), 186197. http://doi.org/10.9770/jesi.2021.9.2(12)

JEL Classifications: L26

\section{Introduction}

Credit rating agencies (CRA) play a pivotal role in the financial markets for providing creditworthiness information to investors and creditors. They provide credit ratings, which reflect the creditworthiness of companies and their ability to pay back the number of loans they borrow from lenders and their potential default (Siddiqui \& Siddiqui, 2015). 


\section{ENTREPRENEURSHIP AND SUSTAINABILITY ISSUES}

ISSN 2345-0282 (online) http://jssidoi.org/jesi/ 2021 Volume 9 Number 2 (December) http://doi.org/10.9770/jesi.2021.9.2(12)

The credit rating process involves gathering baseline information, analyzing it, and assigning an appropriate credit rating. This process is usually not cheap and easy as gaining confidential information has always been complicated. Moreover, companies do not prefer to provide their confidential information to any party that may request it. The solution is to provide confidential information to a third party specializing in assessment procedures and confirm not leaking the information to the market and the competitors. The third party is the Credit Rating Agency (CRA), which can assess and keep confidentiality.

Following the Saudi Vision 2030, Saudi Arabia is now approaching the international markets, and the concentration is on the shift from a hardcore oil-based economy to a more service-based economy, especially financial services economy. First, one of the major initiatives by the Saudi government is to encourage Saudi individuals to start their businesses rather than waiting for employment. In this regard, several initiatives were made, like emphasizing entrepreneurship education at the tertiary level, establishing university business incubators, and making an effective local entrepreneurial ecosystem. Secondly, the Saudi government is minimizing the limitations of non-Saudi investors entering the Saudi financial markets, operating in the Kingdom, and enhancing the role of venture capitalists and angel investors in Saudi Arabia. Still, there is a long way to institutionalize lending without collateral, the prime significance of venture capitalists and angel investors for young entrepreneurs and new startups. Recently, SIMAH Saudi Credit Rating Agency has started functioning as the only CRA in Saudi Arabia. In addition, SIMAH provides confidential reports about the history of the company's loans and their commitment to repayment.

On the other hand, there are many shortcomings in SIMAH's provided information, such as the company's environment, management, processes, and procedures used in operating the company. These factors must be studied to anticipate the level of risk the lender is about to take and assign the appropriate interest rate. After skimming through the literature, it was evident that there is no specific study has ever been conducted in Saudi Arabia on the entrepreneur's perspectives towards their credit rating or credit rating agencies in general.

The impact and critical role of credit rating agencies in the debt market is no more a secret. This CRAs role has gained considerable attention from policymakers and the management of financial institutions after the crises of 2008-2009. In the recent Eurozone crises, this role has become even more prominent (White, 2013). Other factors and information content also accompany the widespread role of CRAs. For example, most credit rating agencies offer more than credit rating services for securities and other financial products by providing other rating outlooks and rating reviews that indicate future credit rating changes (Keenan et al., 1998).

Many studies have covered various aspects of credit rating agencies' working, function, and importance. For example, Holthausen and Leftwich (1986) discuss the credit rating announcement and its impact on stock returns. Similarly, Behr and Güttler (2008) examined the stock market reaction to changes in unsolicited ratings. Bannier and Hirsch (2010) analyzed the other economic functions of credit rating agencies. In addition, some studies have highlighted various stakeholders' perceptions about credit rating agencies, e.g., Einig (2008) for the UK market whereas Madegowda (2010) for the Indian market. However, there is no such study exists for an important Middle Eastern market in Saudi Arabia. This study bridges that gap by providing entrepreneur's opinions towards the credit rating system and CRA in Saudi Arabia. It also highlights the problems faced by entrepreneurs in getting their credit facilities from the local financial markets.

The rest of the study is organized as under; the next section provides the review of literature on CRAs, section 3 provides the objective and methodology of the study, section 4 provides the results and discussion whereas, the conclusion is provided in section 5. 


\section{ENTREPRENEURSHIP AND SUSTAINABILITY ISSUES}

ISSN 2345-0282 (online) http://jssidoi.org/jesi/

2021 Volume 9 Number 2 (December)

http://doi.org/10.9770/jesi.2021.9.2(12)

\section{Literature Review}

Internationally, the credit rating industry is oligopolistic (Becker \& Milbourn, 2008), and three giants Moody's, Standard and Poor's (S\&P), and Fitch, dominate the international scenario for credit rating (Siddiqui \& Siddiqui, 2015). Moody's and S\&P control 80\% of the global market, and Fitch Ratings controls 15\%. (Alessi, Wolverson, \& Sergie, 2013). Other smaller niche players are also in the market, but they took a position in the sector other than the big giants. Table 1 presents the top five credit rating agencies in the world and their scope of work.

Table 1. Top Five International Credit Rating Agencies

\begin{tabular}{|c|c|}
\hline Rating Agency & Scope of Work \\
\hline Standard \& Poor & Comprehensive - covers all entities listed above and more \\
\hline Moody & Comprehensive - covers all entities listed above and more \\
\hline Fitch & Public and Private fixed income securities in the USA \\
\hline IBCA & Financial Institutions, Insurance companies, sovereign countries. \\
\hline Thomson BankWatch & Financial Institutions worldwide \\
\hline Duff \& Phelps & Corporate Debt securities, Securitized Ratings \& insurance companies \\
\hline
\end{tabular}

Three critical observations can be made for credit rating agencies. Firstly, due to its oligopolistic nature, the barriers to entry are higher than in other markets, and this normality requires newcomers to have a tremendous reputation. Thus, the industry is based on reputation, and the awareness about smaller CRAs diminished. Secondly, very high earnings and profit margins are treated as a norm in the industry (Siddiqui \& Siddiqui, 2015). Finally, until the financial crisis in 2008, these "sleepy agencies" were a little-recognized and little-understood part of the financial system. Aftermath, the industry attracted intensive media or political attention and became more aggressive in its marketing tactics (White, 2019).

A credit rating agency (CRA) is usually a recognized or authorized entity that evaluates the organization's creditworthiness and assigns appropriate credit ratings (Ashcraft, \& Duffie, 2006). Ratings are generally a good indicator of the debtor's ability to pay back debt and potential default. Issuers may include governments, corporations, and non-profit organizations (Tang, Peytcheva, \& Li, 2020).

Credit rating agencies play a pivotal role in financial markets, and they offer important information to the potential investors or lenders regarding the current and future projections about the organization seeking funds from capital markets. Literature had mentioned many roles of CRA in financial markets. Firstly, it provides a unique function of assigning ratings to institutions, instruments, and even countries. For example, CRAs assess the institution for their current and future situations (Frost, 2007), evaluate the borrower's performance and ability to repay the debt, and inform the lender (Ellis, Fairchild, \& D'Souza, 2011). CRAs also provide certifications torated institutions for their performance (Driss, Massoud, \& Roberts, 2019) by providing a standard scale to compare companies with each other (Ebenroth, \& Dillon Jr, 1992), and this rating is based on trusted and qualified criteria (White, 2010). This process helps investors judge the investment and its profitability (Ekins, Calabria, \& Brown, 2011). The credit rating process is based on the analyses made on previous years' financial reports (Tullao Jr, Cabuay, \& Hofileña, 2018) and providing feedback to institutions for improvement (Manso, 2013). Secondly, at a macro level, CRAs play a critical role in capital inflow and economic development. (Mutize, \& Nkhalamba, 2021). They help countries and governments improve financial markets and economies (Grima, 2002) and encourage direct foreign investments (Mateev, 2009).

Thirdly, at the national level, CRAs regulate the financial market on behalf of the government (Rahim, 2010). Moreover, they stabilize the financial market (Jorge, 2019, Fong, 2018). They act both as a 'gatekeeper' and as a 'gateway constructor' to the financial markets (Smyth, Cole, \& Fields, 2020), and provide uniformity to the market 


\section{ENTREPRENEURSHIP AND SUSTAINABILITY ISSUES}

ISSN 2345-0282 (online) http://jssidoi.org/jesi/ 2021 Volume 9 Number 2 (December) http://doi.org/10.9770/jesi.2021.9.2(12)

by providing standardized comparisons between organizations (Cantor, \& Packer, 1995). This process enhances the ability of institutions to repay debt (Greer, 2016). Finally, CRAs perform three functions at the micro-level: information management, risk management, and cost management. CRAs provide detailed information about the companies and their performance (Kinato, 2017) and reduce the information asymmetry and lemon problem in the financial market (Rhee, 2015). This act has two obvious benefits, it enhances the confidentiality of information (Kumar, \& Rao, 2012) and reduces information collection costs (Cheng, \& Neamtiu, 2009). For risk management, CRAs help investors and creditors understand the risk level in the investment (Cantor, \& Packer, 1997) to help creditors with their investment risk assessments (Sethuraman, 2019). This process reduces the probability of losses and increases the financial market stability (Fong, 2018). Furthermore, it eventually reduces the risk and encourages investments (Finnerty, Miller, \& Chen, 2013). For cost management, CRAs reduce the cost of debt (Kang \& Ausloos, 2017), cost of regulations (Niedziolka, 2019), and the interest rate for organizations performing better (Mirović, Pavlović, \& Puškarić, 2014). This process helps creditors assign interest rates (Sood, Mays, \& Lindfield, 2012) and decide to increase or decrease interest rates for borrowers depending on the rating results (Jollineau, Tanlu, \& Winn, 2014). Table 2 summarizes the role of credit rating agencies in financial markets.

Table 2. Major Characteristics of Credit Rating Agencies - Summary of the Literature

\begin{tabular}{|c|c|c|c|}
\hline Year & Title & Major Characteristics of CRA & Reference \\
\hline 2021 & $\begin{array}{c}\text { International credit rating agencies in Africa: Perceptions, } \\
\text { trends, and challenges }\end{array}$ & $\begin{array}{l}\text { Plays a critical role in capital inflow and } \\
\text { economic development. }\end{array}$ & $\begin{array}{c}\text { (Mutize, \& } \\
\text { Nkhalamba, 2021) }\end{array}$ \\
\hline 2020 & $\begin{array}{l}\text { From gatekeepers to gateway constructors: Credit rating } \\
\text { agencies and the financialization of housing associations }\end{array}$ & $\begin{array}{l}\text { Acts both as a 'gatekeeper' and 'gateway } \\
\text { constructor' to the financial markets }\end{array}$ & $\begin{array}{l}\text { (Smyth, Cole, \& } \\
\text { Fields, 2020) }\end{array}$ \\
\hline \multirow{3}{*}{2019} & $\begin{array}{c}\text { Are credit rating agencies still relevant? Evidence on } \\
\text { certification from Moody's credit watches }\end{array}$ & $\begin{array}{l}\text { Provides certifications to a rated } \\
\text { institution for their performance. }\end{array}$ & $\begin{array}{l}\text { (Driss, Massoud, } \\
\text { \& Roberts, 2019) }\end{array}$ \\
\hline & $\begin{array}{l}\text { The Visegrád group countries' ratings: Do the CRAs make } \\
\text { the decisions independently or piggyback themselves? }\end{array}$ & Decreases the cost of regulations & (Niedziolka, 2019) \\
\hline & $\begin{array}{l}\text { The effect of reputation shocks to rating agencies on } \\
\text { corporate disclosures }\end{array}$ & $\begin{array}{l}\text { Assists creditors with their investment } \\
\text { risk assessments }\end{array}$ & $\begin{array}{l}\text { (Sethuraman, } \\
\text { 2019). }\end{array}$ \\
\hline \multirow[t]{2}{*}{2018} & Feasibility of a regional credit rating agency for the ASEAN & $\begin{array}{l}\text { Analyzes the financial reports of previous } \\
\text { years. }\end{array}$ & $\begin{array}{l}\text { (Tullao Jr, Cabuay, } \\
\text { \& Hofileña, 2018). }\end{array}$ \\
\hline & China's online peer-to-peer (P2P) lending platforms. & $\begin{array}{l}\text { Reduces the probability of losses and } \\
\text { increases the financial market stability. }\end{array}$ & (Fong, 2018) \\
\hline \multirow{2}{*}{2017} & The impact of credit rating on FDI attraction into Africa & $\begin{array}{l}\text { Provides detailed information about the } \\
\text { companies and their performance }\end{array}$ & (Kinato, 2017) \\
\hline & $\begin{array}{l}\text { An inverse problem study: credit risk ratings as a } \\
\text { determinant of corporate governance and capital structure in } \\
\text { emerging markets: evidence from Chinese listed companies. }\end{array}$ & Decreases the cost of debt & $\begin{array}{l}\text { (Kang, \& Ausloos, } \\
\text { 2017) }\end{array}$ \\
\hline 2016 & $\begin{array}{l}\text { Local government risk assessment: The effect of } \\
\text { government type on credit rating decisions in Texas. }\end{array}$ & $\begin{array}{l}\text { Presents ability of institutions to repay } \\
\text { debt }\end{array}$ & (Greer, 2016) \\
\hline \multirow{2}{*}{2015} & Feedback between credit ratings and financial markets. & Stabilizes the financial market & (Jorge, 2019). \\
\hline & Why credit rating agencies exist. & $\begin{array}{l}\text { Decreases information asymmetry and } \\
\text { lemon problem in the financial market }\end{array}$ & (Rhee, 2015) \\
\hline \multirow[t]{2}{*}{2014} & $\begin{array}{l}\text { Evaluating proposed remedies for credit rating agency } \\
\text { failures. }\end{array}$ & $\begin{array}{l}\text { Help the creditors to decide the interest } \\
\text { rate for the borrower depending on the } \\
\text { rating. }\end{array}$ & $\begin{array}{l}\text { (Jollineau, Tanlu, } \\
\text { \& Winn, 2014) }\end{array}$ \\
\hline & Asset securitization as a means of tourism financing & $\begin{array}{l}\text { Reduces the interest rate for } \\
\text { organizations performing better. }\end{array}$ & $\begin{array}{c}\text { (Mirović, } \\
\text { Pavlović, \& } \\
\text { Puškarić, 2014). }\end{array}$ \\
\hline \multirow[t]{2}{*}{2013} & $\begin{array}{l}\text { The impact of credit rating announcements on credit default } \\
\text { swap spreads }\end{array}$ & $\begin{array}{l}\text { Minimizes the risk and encourages } \\
\text { investments. }\end{array}$ & $\begin{array}{l}\text { (Finnerty, Miller, } \\
\text { \& Chen, 2013). }\end{array}$ \\
\hline & Feedback effects of credit ratings & Provides feedback to institutions & (Manso, 2013) \\
\hline \multirow[t]{2}{*}{2012} & Credit rating-role in the modern financial system. & Enhances the confidentiality of info. & $\begin{array}{l}\text { (Kumar, \& Rao, } \\
\text { 2012) }\end{array}$ \\
\hline & $\begin{array}{c}\text { Subnational Finance for Infrastructure: Potential roles and } \\
\text { opportunities for ADB. }\end{array}$ & Helps creditors to assign an interest rate & $\begin{array}{l}\text { (Sood, Mays, \& } \\
\text { Lindfield, 2012) }\end{array}$ \\
\hline 2011 & Regulation, market structure, and role of the credit rating & Helps investors to judge the investment & (Ekins, Calabria, \& \\
\hline
\end{tabular}




\section{ENTREPRENEURSHIP AND SUSTAINABILITY ISSUES}

ISSN 2345-0282 (online) http://jssidoi.org/jesi/ 2021 Volume 9 Number 2 (December) http://doi.org/10.9770/jesi.2021.9.2(12)

\begin{tabular}{|c|c|c|c|}
\hline & agencies & and its profitability. & Brown, 2011). \\
\hline & $\begin{array}{l}\text { Is imposing liability on credit rating agencies a good idea: } \\
\text { Credit rating agency reform in the aftermath of the global } \\
\text { financial crisis. }\end{array}$ & $\begin{array}{l}\text { Evaluates the borrower's performance } \\
\text { and their ability to repay the debt and } \\
\text { informs the lender }\end{array}$ & $\begin{array}{l}\text { (Ellis, Fairchild, \& } \\
\text { D'Souza, 2011) }\end{array}$ \\
\hline \multirow[t]{2}{*}{2010} & Credit rating agencies' roles have to be reassessed & $\begin{array}{l}\text { Regulates the financial market on behalf } \\
\text { of the government. }\end{array}$ & (Rahim, 2010) \\
\hline & $\begin{array}{c}\text { Using the tools of industrial organization to illuminate the } \\
\text { credit rating industry }\end{array}$ & $\begin{array}{c}\text { Provides rating based on trusted and } \\
\text { qualifying criteria }\end{array}$ & (White, 2010) \\
\hline \multirow[t]{2}{*}{2009} & $\begin{array}{l}\text { Determinants of foreign direct investment in Central and } \\
\text { Southeastern Europe: New empirical tests }\end{array}$ & Encourages direct foreign investments & (Mateev, 2009) \\
\hline & $\begin{array}{c}\text { An empirical analysis of changes in credit rating properties: } \\
\text { Timeliness, accuracy and volatility }\end{array}$ & $\begin{array}{l}\text { Minimizes the cost of information } \\
\text { collection. }\end{array}$ & $\begin{array}{c}\text { (Cheng, \& } \\
\text { Neamtiu, 2009) }\end{array}$ \\
\hline 2007 & $\begin{array}{l}\text { Credit rating agencies in capital markets: A review of } \\
\text { research evidence on selected criticisms of the agencies. }\end{array}$ & $\begin{array}{l}\text { Assesses the institution for their current } \\
\text { and future situations }\end{array}$ & (Frost, 2007) \\
\hline 2002 & An Assessment of Malta's sovereign credit rating. & $\begin{array}{l}\text { Helps countries and governments to } \\
\text { improve financial markets and economy. }\end{array}$ & (Grima, 2002) \\
\hline 1997 & $\begin{array}{l}\text { Differences of opinion and selection bias in the credit rating } \\
\text { industry }\end{array}$ & $\begin{array}{c}\text { Assists investors and creditors to } \\
\text { understand the level of risk in the } \\
\text { investment }\end{array}$ & $\begin{array}{c}\text { (Cantor, \& Packer, } \\
\text { 1997) }\end{array}$ \\
\hline 1995 & The credit rating industry & $\begin{array}{l}\text { Provides uniformity to the market and } \\
\text { provides comparisons between } \\
\text { organizations. }\end{array}$ & $\begin{array}{l}\text { (Cantor, \& Packer, } \\
\text { 1995) }\end{array}$ \\
\hline 1992 & $\begin{array}{l}\text { The international rating game: An analysis of the liability of } \\
\text { rating agencies in Europe, England, and the USA }\end{array}$ & $\begin{array}{l}\text { Provides standard scale to compare } \\
\text { companies with each other. }\end{array}$ & $\begin{array}{c}\text { (Ebenroth, \& } \\
\text { Dillon Jr, 1992) }\end{array}$ \\
\hline
\end{tabular}

It is evident from the above review of previous literature that previous studies focus on evaluating the characteristics and outcomes of CRAs by focusing only on informational, financial, and regulatory benefits of CRAs such as decreasing costs, providing information to investors and other interested parties, and analyzing abilities and financial information of organizations. Moreover, most of the previous took place in developed countries and studied well-established CRAs, operating for long periods, that their outcomes and performance can be readily assessed. Accordingly, it is not easy to generalize the results of these studies to growing markets in developing countries like Saudi Arabia, in which the CRA is only started functioning and is still in its infancy stage. Therefore, it is preferable first to evaluate the acceptability of CRAs and perceptions of entrepreneurs and other stakeholders towards the services provided by CRAs before evaluating their performance and outcomes. Therefore, the present study contributes to the literature by identifying critical factors that contribute to the adoption and success of CRAs in a developing country like Saudi Arabia. In this regard, the study investigated the effect of five factors, namely, creditability, clarity, competence, communications, and customer services, which are rarely investigated in one study in the previous literature. Such contribution may pave the way for other studies to investigate these factors more deeply in other settings to assist decision-makers and entrepreneurs to benefit from CRAs adequately.

\section{Research Objective and Methodology}

This study aimed to examine the entrepreneur's opinion towards credit rating in Saudi Arabia. The questionnaire was extracted from the seminal work of Duff and Einig (2009). The questionnaire measures the entrepreneur's opinion towards CRAs in the financial market and the level of knowledge of the critical parties about CRA's (SIMAH's) role. Different validity checks were applied before adopting the questionnaire into the research, and later amendments were appended accordingly. Firstly, it serves the research objectives and covers the dimensions that need to be covered by the study. Secondly, experts checked it for the face validity of the questionnaire to be used in Saudi Arabia; no changes were suggested. Thirdly it was the most cited questionnaire on the subject and used in many recent studies (Pretorius \& Botha, 2020; Smyth, Cole, \& Fields, 2020; Aktan, Çelik, Abdulla, \& Alshakhoori, 2019; Sajjad \& Zakaria, 2018; Uslu, 2017). Finally, the questionnaire was published in one of the 


\section{ENTREPRENEURSHIP AND SUSTAINABILITY ISSUES}

ISSN 2345-0282 (online) http://jssidoi.org/jesi/ 2021 Volume 9 Number 2 (December) http://doi.org/10.9770/jesi.2021.9.2(12)

top journals, and the authors are well known, and the questionnaires are available online and cost-free. The items measured by a five-point Likert scale start with response categories ranging from strongly agree (given a code of 5) to strongly disagree (given a code of 1).

The sample of 210 participants included entrepreneurs, business incubator managers, venture capitalists, angel investors, bankers, investors, university professors, business incubator employees, and others involved in the entrepreneurial ecosystem in Saudi Arabia. A judgmental sampling technique was employed. Multiple criteria were applied to select the respondents for this research. Firstly, the respondent must be familiar with the local entrepreneurial ecosystem and the role of CRAs in the economy, and credit rating processes adopted by CRAs. Therefore, efforts were made to ensure that all respondents know CRAs and consider the Saudi Credit Rating Agency (SIMAH). All faculty members who participated in this survey had a doctoral degree in finance and have taught accounting and finance-related courses, including money and banking, finance principles, financial management, derivatives, insurance, portfolio management, and analysis of financial statements. Secondly, respondents must be at least a graduate, preferably in the business discipline. Many doctors and engineers also participated in the survey having an MBA degree with a major in finance, but all of them are entrepreneurs and have already started their ventures or are in the process of starting their ventures. Although no gender-based quota was allocated, all efforts were made to make the sample all-inclusive. Thirdly, it is worth mentioning that the researcher approached the experts and investors from a larger population to extract pertinent findings related to the research subject. All efforts were made to select the respondents based on their level of involvement in the local ecosystem and willingness to participate. Sampling focused on randomizing the education, profession, age, and gender $(\mathrm{N}=210)$. Table 3 presents the demographic data of the respondents.

Table 3. Respondent's demographic data

\begin{tabular}{|c|c|c|c|}
\hline Variable & Response Category & Frequency & Percent \\
\hline \multirow{2}{*}{ Gender } & Male & 189 & $10.1 \%$ \\
\cline { 2 - 4 } & Female & 21 & $89.9 \%$ \\
\hline \multirow{3}{*}{ Age } & Up to 24 years & 32 & $15.2 \%$ \\
\cline { 2 - 4 } & $25-34$ years & 104 & $49.5 \%$ \\
\hline \multirow{3}{*}{ Education } & Above 35 years & 74 & $35.3 \%$ \\
\cline { 2 - 4 } & Master's degree & 32 & $15.2 \%$ \\
\cline { 2 - 4 } & Bachelor's degree & 116 & $55.2 \%$ \\
\hline \multirow{3}{*}{ Profession } & Diploma & 122 & $30.0 \%$ \\
\cline { 2 - 4 } & Entrepreneurs, Startup founders & 47 & $22.3 \%$ \\
\cline { 2 - 4 } & Banker / Insurance / financial services & 24 & $11.4 \%$ \\
\cline { 2 - 4 } & Venture Capitalists/ Angel Investors/Incubators & 17 & $9.0 \%$ \\
\hline
\end{tabular}

\section{Results and Discussion}

Data were analyzed in many systematic stages. Firstly, respondent's profiles were analyzed to see data was collected from different backgrounds. Secondly, it was analyzed using descriptive analyses using frequency distribution, and finally, it was analyzed using Exploratory Factor Analyses (EFA). For this research, EFA was considered appropriate based on three reasons. Firstly, EFA is used where there are no pre-conceived theories or expectations, and the nature of research is exploratory; therefore, EFA was considered more suitable. Secondly, EFA uncovers the underlying structure of relatively large variables (Hair, Anderson, Tatham \& Black, 2006). Finally, EFA was also successfully adopted in an earlier study on credit rating agencies (Duff and Einig, 2009). All factor analyses were performed using the Principal Factor Analysis extraction method with the Varimax rotation method. The factor loading criteria were applied, which required that (a) a factor must have at least three salient item loadings greater than 0.3, (b) individual items must have at least one-factor loading greater than 0.3 , (c) any item loading on more than one factor when the final solution is obtained will be placed only in the factor on which it loads most highly (Hair et al., 2006). 


\section{ENTREPRENEURSHIP AND SUSTAINABILITY ISSUES}

ISSN 2345-0282 (online) http://jssidoi.org/jesi/ 2021 Volume 9 Number 2 (December) http://doi.org/10.9770/jesi.2021.9.2(12)

The collected data was analyzed for the missing values, and the missing values were corrected. The number of missing values was not significant, there was a missing value found in some questions, and these missing values were fixed by assigning the neutral value to the responses. All questions were analyzed on normality tests for factor analyses as all questions were found normally distributed.

Analysis of 44 items related to the credit rating agency was factor analyzed using the Principal Factor Analysis extraction method with Varimax rotation method, yielded a five-factor solution, to which various criteria were then applied for refinement. Initially, the solution was examined to determine whether all the factors satisfied the Kaiser criterion (eigenvalues $>1$ ), and they did. Secondly, the resulting scree plot was examined from which considerable discontinuity after factor three emerged, suggesting a three-factor solution. On a final reading of the individual items for coherence, no doubts arose concerning the coherence of the factors. All the items loading on each separate factor were found to cohere to some degree, and therefore they were included in their respective factors. Table 4 shows exploratory factor analysis for critical success factors for credit rating agencies in Saudi Arabia.

The analyses resulted in a final five-factor solution, comprised of 44 items, all with communality values greater than 0.3. No item was dropped during the Exploratory Factor Analysis. Bartlett's test of Sphericity was significant, and the Kaiser-Meyer-Olkin measure of sampling adequacy is far greater than 0.6, namely KMO = 0.944. This means that the variables correlate to each other, which is needed to find an underlying factor that represents a grouping of variables (Burn \& Burns, 2008; Coakes, 2013; Hejase et al., 2014). Having a suitable KMO for the data shows that the data was suitable for factor analysis. The questionnaire contained 44 questions of different aspects; these questions showed that the concern of the CRAs and the most critical factors are five, and these aspects are (Credibility, Clarity, Competence, Communications, and Customer Services). The analysis conducted (see Table 4) has shown each item against the factor with the highest likelihood occurrence.

Factor 1 had an eigenvalue of 26.36, and it accounted for $59.9 \%$ of the cumulative variance. It had loadings on 21 items. This factor was labeled as 'Credibility.' Factor 2 had an eigenvalue of 2.34, and it accounted for $62.3 \%$ of the cumulative variance with loadings on nine items. This factor has been labeled as 'Clarity.' Factor 3 had an eigenvalue of 1.84 , and it accounted for $64.1 \%$ of the cumulative variance. This factor has been labeled as 'Competence.' Factor 4 had an eigenvalue of 1.33, and it accounted for $67.1 \%$ of the cumulative variance. This factor has been labeled as 'Communications.' Finally, factor 5 had an eigenvalue of 1.21, accounting for $69.89 \%$ of the cumulative variance. This factor has been labeled as 'Customer Services.'

Table 4. EFA - Critical Success Factor for Credit Rating Agencies

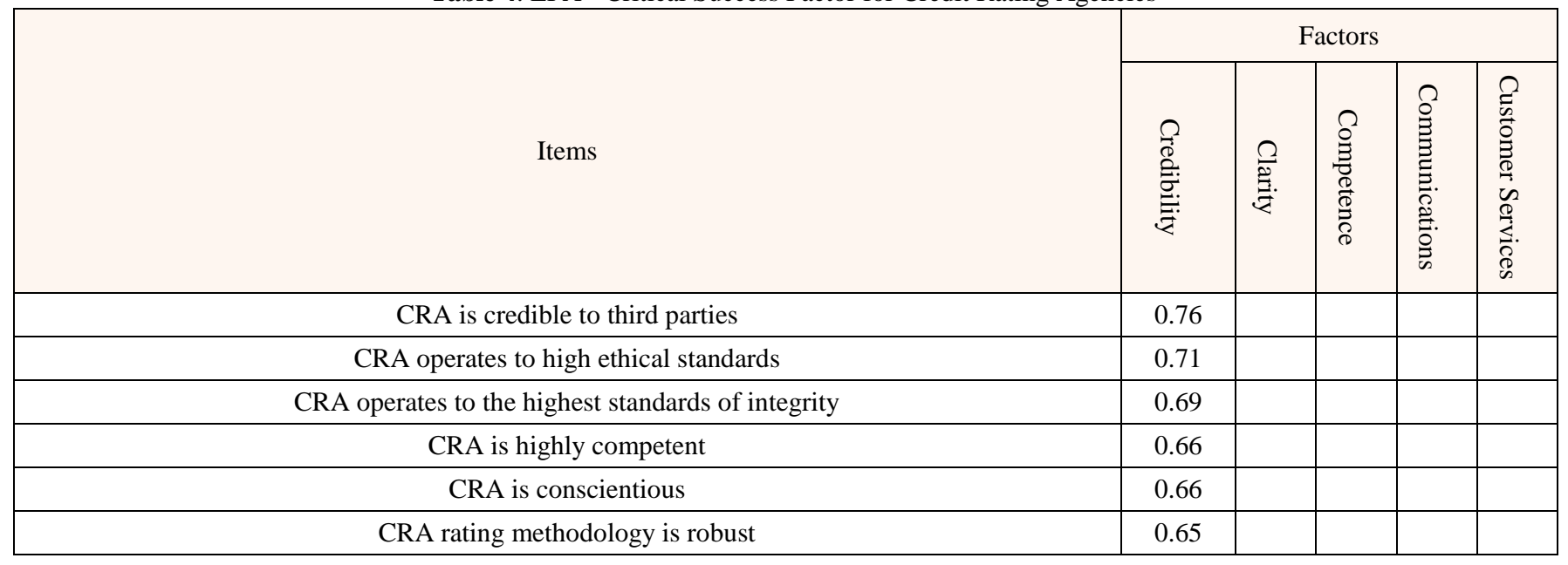




\begin{tabular}{|c|c|c|c|c|c|}
\hline CRA is proactive in its ratings & 0.64 & & & & \\
\hline CRA ratings are accurate & 0.61 & & & & \\
\hline CRA rating methodology is consistent across the sector & 0.53 & & & & \\
\hline CRA outputs/reports are factually correct & 0.58 & & & & \\
\hline CRA adjusts its ratings on a timely basis & 0.51 & & & & \\
\hline CRA analyst is actively involved in the rating process & & 0.61 & & & \\
\hline CRA analyst is very knowledgeable about an issuer's industry & & 0.61 & & & \\
\hline CRA analysts' benefits are not linked to the issuer's revenue & & 0.61 & & & \\
\hline CRA publishes all assumptions and methods relevant to its decisions & & 0.55 & & & \\
\hline CRA keep issuers, investors, and market participants well informed about rating developments & & 0.55 & & & \\
\hline CRA analyst is keen to understand details about the issuer's organization & & 0.54 & & & \\
\hline CRA analysts' promotion prospects are not dependent on their ability to generate ancillary & & 0.52 & & & \\
\hline CRA and issuers keep informed each other about the latest developments & & 0.51 & & & \\
\hline CRA analysts should not change repeatedly & & 0.45 & & & \\
\hline CRA regularly evaluates the performance of its staff & & & 0.65 & & \\
\hline CRA and issuer keep each other informed about what is going on & & & 0.64 & & \\
\hline CRA employs a well-qualified and educated staff & & & 0.61 & & \\
\hline CRA team and an issuer have frequent communications & & & 0.63 & & \\
\hline CRA and issuer's relationship is based on mutual trust & & & 0.59 & & \\
\hline CRA and investors have a high level of trust & & & 0.58 & & \\
\hline CRA staff undertake regular professional development & & & 0.57 & & \\
\hline CRA staff have an appropriate workload & & & 0.57 & & \\
\hline CRA makes a genuine effort to resolve problems (relationship issues) & & & 0.56 & & \\
\hline CRA rating take cyclicality into account & & & 0.53 & & \\
\hline CRA communicates well to issuers its targets for an issuer's performance (upgrades) & & & & 0.72 & \\
\hline CRA communicates well to investors its targets for an issuer's performance (upgrades) & & & & 0.71 & \\
\hline CRA allows issuers a 'right of appeal' to correct factual errors and misrepresentations & & & & 0.71 & \\
\hline Investors well understand CRA's methodologies & & & & 0.65 & \\
\hline Issuers well understand CRA's methodologies & & & & 0.62 & \\
\hline CRA can negotiate discounts for frequent issuers & & & & 0.61 & \\
\hline CRA's publications explain its methodology to investors and others & & & & 0.62 & \\
\hline CRA employs staff with adequate experience & & & & 0.57 & \\
\hline CRA analyst provides an issuer with individual attention & & & & 0.52 & \\
\hline CRA regularly conducts client service review meetings & & & & & 0.73 \\
\hline CRA analyst regularly meets with an issuer's key personnel to identify & & & & & 0.72 \\
\hline CRA analyst is easily contactable by telephone/e-mail by issuers & & & & & 0.69 \\
\hline CRA discloses a detailed fee scheme to potential issuers & & & & & 0.65 \\
\hline CRA and issuers have a high level of trust & & & & & 0.55 \\
\hline
\end{tabular}




\section{ENTREPRENEURSHIP AND SUSTAINABILITY ISSUES}

ISSN 2345-0282 (online) http://jssidoi.org/jesi/

2021 Volume 9 Number 2 (December)

http://doi.org/10.9770/jesi.2021.9.2(12)

\section{Conclusions}

This research aimed to examine the entrepreneur's opinions towards their credit rating and CRA in Saudi Arabia. It also involved problems faced by entrepreneurs in getting their credit facilities from the local financial markets. The study has adopted the questionnaire from pioneering research on CRAs by Duff and Einig (2009). A sample of 210 respondents participated in this survey comprising entrepreneurs, venture capitalists, angel investors, business incubator employees, bankers, university professors, engineers, doctors, and other professionals. Descriptive statistics and Exploratory Factor Analyses were used to analyze the data. Findings show five critical factors are affecting CRAs in Saudi Arabia, i.e., (1) Credibility, (2) Clarity, (3) Competence, (4) Communications, and (5) Customer Services. Factor 1 was labeled as 'Credibility.' It reflects that credibility is the most critical factor in the credit rating business (Jollineau, Tanlu, \& Winn, 2014). Most likely, all stakeholders in the financial market seek accurate information to make the right decision, which makes the credibility of the information provided the most profound concern. Therefore, credit rating agencies provide accurately and trusted information (Siddiqui \& Siddiqui, 2015). Factor 2 was named 'Clarity.' It reflects the second most important factor in credit rating businesses. The clarity and transparency of rating processes are the key to the credit rating business (de Meijer, \& Saaf, 2008; Krishnan, Mukherji, \& Basu, 2020) and must be prepared by high standards of professionalism. Factor 3 was labeled as 'Competence.' Credit rating is an investor service, and a rating agency is expected to maintain the highest possible level of analytical competence and integrity (Kumar \& Rao, 2012), and issuers also tend to view the competence of CRA analytic staff as a critical component of rating quality (Duff \& Einig, 2015). Factor 4 was labeled as 'Communications.' The communication conducted is weak between the CRA and the beneficiary. The analysis provided could be missing critical information which will affect the decision-makers and the decisions made toward the company (Moloney, 2011). Factor 5 was marked as 'Customer Services. 'Positive relationships between the CRAs and their clients will help the value and strength of the information provided. The relationship factor shows how the respondents see the importance of relationships between the CRAs and their clients. All five factors mentioned above are in line with the findings of earlier research.

The study results add to the literature about CRAs by first identifying critical factors that facilitate acceptance and success of CRAs, relevant to developing countries like KSA. Moreover, the study ranked these factors in terms of their effect and importance to entrepreneurs. Investigation of these factors is lacking in the previous studies, especially those conducted in developing countries. The paper highlights important factors that can assist in setting performance standards of CRAs. Therefore, scientists and researchers can benefit from this study by building on these factors in future studies to show if they have similar effects in other countries and obtain larger samples from these countries to generalize their effect on CRAs decisions and performance. It would also be interesting to investigate how the effect of these factors is different among different sizes and structures of CRAs. The study presents several recommendations to different stakeholders. Firstly, government agencies should understand that credit rating agencies play a pivotal role in the financial deepening of local financial markets and should get a separate set of laws and regulations for new startups and entrepreneurs. Furthermore, CRA in Saudi Arabia should enhance their creditability, clarity, and transparency, staff competence for financial and credit analyses, communications, and customer services. Being in monopolistic condition and lack of competition may inversely affect CRA's critical factors, especially credibility and customer services. Therefore, ministries eliminate substantial obstacles and develop more flexible rules and regulations for the credit rating industry. Secondly, there is a need to improve the awareness and understanding of 'credit rating culture. 'SIMAH has partially achieved this through indirect sources, but there is a need to offer awareness sessions through universities, especially business schools teaching capital market and financial management courses. In addition, there should be seamless efforts to make credit rating part of the business school's curriculum. This can be achieved in consultation with the ministry of education to re-organize the finance courses in all universities/business schools to focus more on local capital markets and the role of CRAs in financial markets. 


\section{ENTREPRENEURSHIP AND SUSTAINABILITY ISSUES}

ISSN 2345-0282 (online) http://jssidoi.org/jesi/ 2021 Volume 9 Number 2 (December)

http://doi.org/10.9770/jesi.2021.9.2(12)

Finally, managers at CRAs should also improve their commitments to get the customers' confidence for CRA's credibility, clarity, competence, communications, and customer services.

This research is an outcome of overcoming many limitations. These limitations include lack of resources relevant to credit rating in Saudi Arabia, availability of limited credit rating literature, and general know-how in Saudi Arabia. Moreover, the difficulty of accessing credit rating experts from all over the Kingdom is another limitation. Therefore, findings must be considered cautiously and cannot be generalized. Notwithstanding, that the outcomes are essential as an eye-opener to researchers and financial professionals.

\section{References}

Aktan, B., Çelik, Ş., Abdulla, Y., \& Alshakhoori, N. (2019). The impact of credit ratings on capital structure. ISRA International Journal of Islamic Finance, 11(2) http://doi.org/10.1108/ijif-03-2018-0028

Alessi, C., Wolverson, R., \& Sergie, M. A. (2013). The credit rating controversy. Council on foreign relations.

Ashcraft, A., \& Duffie, D. (2006). Systemic Dynamics in the Federal Funds Market. Federal Reserve Bank of New York. https://www.newyorkfed.org/medialibrary/media/newsevents/events/research/2006/0518-slides_duffie.pdf

Bannier, C. E., \& Hirsch, C. W. (2010). The economic function of credit rating agencies-What does the Watchlist tell us? Journal of Banking \& Finance, 34(12), 3037-3049. https://doi.org/10.1016/j.jbankfin.2010.07.002

Becker, B., \& Milbourn, T. (2008). Reputation and competition: evidence from the credit rating industry. Harvard Business School.

Behr, P., \& Güttler, A. (2008). The informational content of unsolicited ratings. Journal of Banking \& Finance, 32(4), 587-599. https://doi.org/10.1016/j.jbankfin.2007.04.021

Burns, R.B., \& Burns, R.A. (2008). Business Research Methods and Statistics Using SPSS. London: SAGE Publications Ltd.

Byoun, S., Han, S. H., \& Shin, Y. S. (2020). Does the nationally recognized statistical rating organization certification matter for Japanese credit rating agencies? Journal of Financial Markets, 100585 https://doi.org/10.1016/j.finmar.2020.100585

Cantor, R., \& Packer, F. (1995). The credit rating industry. The Journal of Fixed Income, 5(3), 10-34.

Cantor, R., \& Packer, F. (1997). Differences of opinion and selection bias in the credit rating industry. Journal of Banking \& Finance, 21(10), 1395-1417.

Cheng, M., \& Neamtiu, M. (2009). An empirical analysis of changes in credit rating properties: Timeliness, accuracy and volatility. Journal of Accounting and Economics, 47(1-2), 108-130. https://doi.org/10.1016/j.jacceco.2008.11.001

Coakes, S.J. (2013). SPSS Version 20.0 for Windows: Analysis without Anguish. Milton, Queensland: John Wiley \& Sons Australia, Ltd.

de Meijer, C. R., \& Saaf, M. H. (2008). The credit crunch and credit rating agencies: Are they really striving towards more transparency?. Journal of Securities Law, Regulation \& Compliance, 1(4),

Driss, H., Massoud, N., \& Roberts, G. S. (2019). Are credit rating agencies still relevant? Evidence on certification from Moody's credit watches. Journal of Corporate Finance, 59, 119-141. https://doi.org/10.1016/j.jcorpfin.2016.08.003

Duff, A., \& Einig, S. (2015). Debt issuer: Credit rating agency relations and the trinity of solicitude: An empirical study of the role of commitment. Journal of business ethics, 129(3), 553-569. https://doi.org/10.1007/s10551-014-2175-y

Ebenroth, C. T., \& Dillon Jr, T. J. (1992). The international rating game: An analysis of the liability of rating agencies in Europe, England, and the United States. Law \& Pol'y Int'l Bus., 24, 783.

Einig, S. E. (2008). Financial managers', institutional investors' and other interested parties' perception of credit rating agencies and rating quality University of the West of Scotland.

Ekins, E. E., Calabria, M. A., \& Brown, C. O. (2011). Regulation, market structure, and role of the credit rating agencies. In APSA 2011 Annual Meeting Paper.

Ellis, N. S., Fairchild, L. M., \& D'Souza, F. (2011). Is imposing liability on credit rating agencies a good idea: Credit rating agency reform in the aftermath of the global financial crisis. Stan. JL Bus. \& Fin., 17, 175.

Finnerty, J. D., Miller, C. D., \& Chen, R. R. (2013). The impact of credit rating announcements on credit default swap spreads. Journal of Banking \& Finance, 37(6), 2011-2030.

Fong, M. W. (2018). China's online peer-to-peer (P2P) lending platforms. In The Digitization of Business in China (pp. 43-74). Palgrave Macmillan, Cham.

Frost, C. A. (2007). Credit rating agencies in capital markets: A review of research evidence on selected criticisms of the agencies. Journal of Accounting, Auditing \& Finance, 22(3), 469-492. https://doi.org/10.1177/0148558X0702200306

Greer, R. A. (2016). Local government risk assessment: The effect of government type on credit rating decisions in Texas. Public Budgeting \& Finance, 36(2), 70-90.

Grima, M. (2002). An Assessment of Malta's Sovereign Credit Rating. Bank<Valletta>: Bank of Valletta Review, (25), 30-50.

Hair, J. F., Black, W. C., Babin, B. J., Anderson, R. E., \& Tatham, R. (2006). Multivariate data analysis. Uppersaddle River.

Hejase, A.J., \& Hejase, J.H. (2013). Research Methods: A Practical Approach for Business Students. $2^{\text {nd }}$ ed. Philadelphia, PA: Masadir Inc. 


\section{ENTREPRENEURSHIP AND SUSTAINABILITY ISSUES}

ISSN 2345-0282 (online) http://jssidoi.org/jesi/ 2021 Volume 9 Number 2 (December)

http://doi.org/10.9770/jesi.2021.9.2(12)

Hejase, H.J., Haddad, Z., Hamdar, B., Al Ali, R., Hejase, A.J., \& Beyrouti, N. (2014). Knowledge Sharing: Assessment of Factors Affecting Employee' Motivation and Behavior in the Lebanese Organizations. Journal of Scientific Research \& Reports, 3(12), 15491593. https://doi.org/10.9734/JSRR/2014/8107

Holthausen, R. W., \& Leftwich, R. W. (1986). The effect of bond rating changes on common stock prices. Journal of Financial Economics, 17(1), 57-89.

Jollineau, S. J., Tanlu, L. J., \& Winn, A. (2014). Evaluating proposed remedies for credit rating agency failures. The Accounting Review, 89(4), 1399-1420. https://doi.org/10.2308/accr-50721

Jorge, J. (2019). Feedback effects between credit ratings and financial markets. Economic Modelling, 80, 328-338. https://doi.org/10.1016/j.econmod.2018.11.019

Kang, M., \& Ausloos, M. (2017). An inverse problem study: credit risk ratings as a determinant of corporate governance and capital structure in emerging markets: evidence from Chinese listed companies. Economies, 5(4), 47.

Keenan, S., Fons, J., \& Carty, L. (1998). A historical analysis of Moody's Watchlist. Moody's Investors Service.

Kinato, H. A. (2017). The Impact of Credit Rating on FDI Attraction into Africa. https://thesis.eur.nl/pub/42573

Krishnan, K., Mukherji, A., \& Basu, S. (2020). Market responses to increased transparency: An Indian narrative. International Review of Economics \& Finance, 69, 663-677.

Kumar, K. V., \& RAO, S. H. (2012). Credit Rating-Role in Modern Financial System. International Journal of Marketing, Financial Services \& Management Research, 1(8), 126-138.

Madegowda, J. (2010). Working of Credit Rating Agencies in India: An Analysis of Investors' Perception. IUP Journal of Behavioral Finance, 7.

Manso, G. (2013). Feedback effects of credit ratings. Journal of Financial Economics, 109(2), 535-548.

Mateev, M. (2009). Determinants of foreign direct investment in Central and Southeastern Europe: New empirical tests. Oxford Journal, 8(1), 133-149.

Mirović, V., Pavlović, N., \& Puškarić, A. (2014). Asset Securitization as a Means of Tourism Financing. Economic Insights-Trends \& Challenges, 66(2).

Mutize, M., \& Nkhalamba, M. P. (2021). International credit rating agencies in Africa: Perceptions, trends and challenges. International Journal of Sustainable Economy, 13(1), 55-71. . http://doi.org/10.1504/IJSE.2021.113303

Niedziolka, P. (2019). The Visegrád Group Countries' Ratings-Do the Credit Rating Agencies Make the Decisions Independently or Piggyback Themselves?. Journal of Economics and Business, 2(2).

Pretorius, M., \& Botha, I. (2020). Leads and Lags in African Sovereign Credit Ratings. Journal of African Business, 1-19.

Rahim, M. M. (2010). Credit rating agencies' roles have to be reassessed. Law and Financial Markets Review, 4(4), 433-438.

Rhee, R. J. (2015). Why credit rating agencies exist. Economic Notes: Review of Banking, Finance and Monetary Economics, 44(2), 161176. https://doi.org/10.1111/ecno.12034

Sajjad, F., \& Zakaria, M. (2018). Credit rating as a mechanism for capital structure optimization: Empirical evidence from panel data analysis. International Journal of Financial Studies, 6(1), 13. RePEc:gam:jijfss:v:6:y:2018:i:1:p:13-:d:128713

Sethuraman, M. (2019). The effect of reputation shocks to rating agencies on corporate disclosures. The Accounting Review, 94(1), 299326. https://doi.org/10.2308/accr-52114

Siddiqui, A., \& Siddiqui, K. (2015). Credit-Rating Business in Pakistan: Norms \& Practices. Sci. Int. (Lahore), $27(5), 4597-4602$.

SIMAH Saudi Credit Rating Agency https://www.simah.com/en/personal/pages/default.aspx

Smyth, S., Cole, I., \& Fields, D. (2020). From gatekeepers to gateway constructors: Credit rating agencies and the financialization of housing associations. Critical Perspectives on Accounting, 71, 102093.

Smyth, S., Cole, I., \& Fields, D. (2020). From gatekeepers to gateway constructors: Credit rating agencies and the financialization of housing associations. Critical Perspectives on Accounting, 71 http://doi.org/10.1016/j.cpa.2019.102093

Sood, P., Mays, M. M., \& Lindfield, M. R. (2012). Subnational Finance for Infrastructure: Potential Roles and Opportunities for ADB. Accessed from https://www.think-asia.org/bitstream/handle/11540/1384/adb-wp20-subnational-finance-infrastructure.pdf?sequence=1

Tang, L., Peytcheva, M., \& Li, P. (2020). Investor-paid ratings and conflicts of interest. Journal of Business Ethics, 163(2), $365-378$.

Tullao Jr, T. S., Cabuay, C. J. R., \& Hofileña, D. S. (2018). Is a Regional Credit Rating Agency for the ASEAN Feasible? DLSU Business \& Economics Review, 27(2), 35-50. http://dlsu-ber.com/wp-content/uploads/2018/03/4Tullao-011818.pdf

Uslu, Ç. L. (2017). Examining the Behavior of Credit Rating Agencies Post 2008 Economic Turmoil. International Journal of Management and Economics, 53(4), 61-76. https://doi.org/10.1515/ijme-2017-0026

White, L. J. (2013). Credit rating agencies: An overview. Annu. Rev. Financ. Econ., 5(1), 93-122. https://doi.org/10.1146/annurev-

financial-110112-120942

White, L. J. (2019). Using the tools of industrial organization to illuminate the credit rating industry. Japanese Economic Review, 70(3), 367-374. https://doi.org/10.1111/jere.12238 


\section{ENTREPRENEURSHIP AND SUSTAINABILITY ISSUES}

ISSN 2345-0282 (online) http://jssidoi.org/jesi/

2021 Volume 9 Number 2 (December)

http://doi.org/10.9770/jesi.2021.9.2(12)

Dr. Kamran SIDDIQUI is an Associate Professor of Marketing and Entrepreneurship at the College of Business Administration, Imam Abdulrahman Bin Faisal University, Saudi Arabia. Research interests: entrepreneurship, business incubators, and accelerators, entrepreneurial marketing, venture capital.

ORCID ID: 0000-0002-5724-0991

Dr. Ishtiaq Ahmed BAJWA is an Assistant Professor of Finance at College of Business Administration, Imam Abdulrahman Bin Faisal University, Saudi Arabia. Research interests: entrepreneurial finance, venture capital, and fin-tech.

ORCID ID: 0000-0001-5296-0028

Dr. Faisal Al-HUDITHI is an Assistant Professor of Accounting and Dean at College of Business Administration, Imam Abdulrahman Bin Faisal University, Saudi Arabia. Research interests: Management Accounting, Accounting Curriculum, Venture Capital

ORCID ID: 0000-0002-0342-420X

Dr. Tarig ELTAYEB is an Assistant Professor of Management at College of Business Administration, Imam Abdulrahman Bin Faisal University, Saudi Arabia. Research interests: Management, Supply Chain Management, Operations Management.

ORCID ID: 0000-0002-7125-2171

Dr. Asma KHATOON is an Assistant Professor of Accounting at College of Business Administration, Imam Abdulrahman Bin Faisal University, Saudi Arabia. Research interests: Accounting \& Venture Capital.

ORCID ID: 0000-0003-2704-7776

Mr. Suliman BAWARDI is a graduate student at the College of Business Administration, Imam Abdulrahman Bin Faisal University, Saudi Arabia.

ORCID ID: 0000-0002-3017-6715

Make your research more visible, join the Twitter account of ENTREPRENEURSHIP AND SUSTAINABILITY ISSUES: @Entrepr69728810

Copyright (C) 2021 by author(s) and VsI Entrepreneurship and Sustainability Center

This work is licensed under the Creative Commons Attribution International License (CC BY).

http://creativecommons.org/licenses/by/4.0/

(c) (i) Open Access 